\title{
An economic analysis of cucumber (Cucumis sativus L.) cultivation in eastern zone of Haryana (India) under polyhouse and open field condition
}

\author{
Parveen Kumar*, R. S. Chauhan and R. K. Grover \\ Department of Agricultural Economics, CCS Haryana Agricultural University, Hisar- 125004 (Haryana), INDIA \\ *Corresponding author E-mail: parv2509@gmail.com \\ Received: June 28, 2016; Revised received: December 7, 2016; Accepted: February 7, 2017
}

\begin{abstract}
The study was conducted in north zone of Haryana (India) state to find out the economic analysis of cucumber cultivation under polyhouse and open field condition. The primary data was collected by personal interview of the selected respondents with the help of well-designed and pre tested schedule. Simple statistical tools like average and percentage were used to calculate the economics of the crop. In the present study, it was found that the cost of cultivation of cucumber per acre under polyhouse was Rs. 283684.40 while in case of open field condition it was Rs. 98003.39. In case of production and net returns, it was higher per acre in polyhouse; 245.47quintal and Rs. 97138.68, respectively. Present study concluded that yield and income of farmers can be increased with help of polyhouse technology in case of cucumber cultivation.
\end{abstract}

Keywords: Cost of cultivation, Economic analysis, Open field condition, Polyhouse, Returns

\section{INTRODUCTION}

Cucumber (Cucumis sativus L.) known as Khira in Hindi is an important summer vegetable, commonly grown throughout India. The cucumber is a warm season crop and grows best at a temperature between $18^{\circ} \mathrm{C}$ and $24^{\circ} \mathrm{C}$. Cucumber is short duration (90-100 days) crop. The cucumber is originally from Southern Asia, but now grows on most continents. In India, the area and production under cucumber is 44,000 ha and 685,000 tonne per ha (Anonymous, 2015). In Haryana, cucumber was grown all over the year in polyhouse. First crop of cucumber was planted in August and prolonged up to November. Second crop was planted in December and prolonged up to March. Third crop of cucumber was planted in April and prolonged up to June. In open field condition cucumber was planted in February and harvested up to April-May. Cropping intensity of cucumber was $300 \%$ in polyhouse condition (Anonymous, 2012). The present study has made an attempt to have economic analysis of cucumber cultivation in eastern zone of Haryana (India) under polyhouse and open field conditions.

\section{MATERIALS AND METHODS}

The primary data was collected in the agricultural year 2013-14. To fulfill the specific objective of the study, simple statistical tools like average and percentage were used to compare, contrast and interpret results properly. To collect the primary data, multistage random sampling technique was used. Karnal district was purposely selected on the basis of predominance of cucumber cultivation both under polyhouse and open field condition. Gharaunda and Indri blocks were selected on the basis of predominance cucumber cultivation under polyhouse and open field. There after two villages from each block were selected. Ten respondents, each under polyhouse and open field condition were randomly selected from each village, thus making a total sample of 80 respondents. In polyhouse Hiltan and Multistar varities of cucumber and in open field conditions hybrids seeds of cucumber were grown.

\section{RESULTS AND DISCUSSION}

To fulfill the objective of study, economic analysis of cucumber cultivation in eastern zone of Haryana (India) under polyhouse and open field condition were made on per acre basis. As shown in table 1 cost of cultivation of cucumber under polyhouse was worked out to be Rs. 163182.37. The cost structure of the variable cost shows that the highest proportion was spent on seed with Rs. 70871.9 (24.98\%) followed by harvesting, fertilizer and FYM, plant protection, ridging/bed preparation, field preparation, weed control and irrigation charges with Rs. 36479.16 (12.86\%), Rs. 11978.4 (4.22\%), Rs. 11256.94 (3.97\%), Rs. 7694.44 $(2.71 \%)$, Rs. $6350(2.24 \%)$, Rs. 3863.88 (1.36\%) and Rs. $1213.88(0.43 \%)$ respectively. Findings are in agreement with the study Sreedhara et al. (2013) who reported the labour cost, expenditure on material cost, total cost of cultivation, was higher under protected structure in Karnataka. In case of open field cultivation of cucumber, the total variable cost was worked out to 
Table 1. Economic analysis of cucumber cultivation in eastern zone of Haryana (India) under polyhouse and open field condition (Rs. /acre).

\begin{tabular}{|c|c|c|c|c|c|}
\hline $\begin{array}{l}\text { S. } \\
\mathbf{N} .\end{array}$ & Particulars & $\begin{array}{l}\text { Polyhouse } \\
\text { cultivation }\end{array}$ & $\begin{array}{l}\text { Open field } \\
\text { cultivation }\end{array}$ & \multicolumn{2}{|c|}{$\begin{array}{c}\text { Difference between polyhouse and } \\
\text { open field condition }\end{array}$} \\
\hline \multicolumn{2}{|c|}{ Cost structure } & & & $\begin{array}{l}\text { Rs. difference } \\
\text { over open field } \\
\text { condition }\end{array}$ & $\begin{array}{c}\% \text { difference over } \\
\text { open field } \\
\text { condition }\end{array}$ \\
\hline 1 & Field preparation & $6350(2.24)$ & $4289.47(4.38)$ & 2060.53 & 48.04 \\
\hline 2 & Ridging/bed preparation & $7694.44(2.71)$ & $1926.31(1.97)$ & 5768.13 & 299.44 \\
\hline 3 & Seed & $70871.9(24.98)$ & $5394.73(5.50)$ & 65477.17 & 1213.73 \\
\hline 4 & Fertilizer and manure & $11978.4(4.22)$ & $7252.1(7.40)$ & 4726.3 & 65.17 \\
\hline 5 & Irrigation & $1213.88(0.43)$ & $1347.36(1.37)$ & -133.48 & -9.91 \\
\hline 6 & Plant protection & $11256.94(3.97)$ & $8000(8.16)$ & 3256.94 & 40.71 \\
\hline 7 & Weed control & $3863.88(1.36)$ & $4778.94(4.88)$ & -915.06 & -19.15 \\
\hline 8 & Harvesting & $36479.16(12.86)$ & $30505.26(31.13)$ & 5973.9 & 19.58 \\
\hline 9 & Subtotal (1 to 8$)$ & $149708.6(52.77)$ & 63494.17 (64.79) & 86214.43 & 135.78 \\
\hline 10 & $\begin{array}{l}\text { Interest on working } \\
\text { capital }\end{array}$ & $13473.77(4.75)$ & $5714.47(5.83)$ & 7759.3 & 135.78 \\
\hline 11 & Variable cost $(9+10)$ & $163182.37(57.52)$ & $69208.65(70.62)$ & 93973.72 & 135.78 \\
\hline 12 & Marketing cost & $16644.47(5.86)$ & $4953.01(5.05)$ & 11691.46 & 236.05 \\
\hline 13 & Management charge & $16318.23(5.75)$ & $6920.86(7.06)$ & 9397.37 & 135.78 \\
\hline 14 & Risk factor & $16318.23(5.75)$ & $6920.86(7.06)$ & 9397.37 & 135.78 \\
\hline 15 & $\begin{array}{l}\text { Depreciation and } \\
\text { interest on fixed capital }\end{array}$ & $53489.13(18.85)$ & 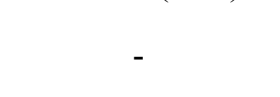 & - & - \\
\hline 16 & Rental value of land & $17731.95(6.25)$ & $10000(10.20)$ & 7731.95 & 77.32 \\
\hline 17 & Total cost (11 to 16$)$ & $283684.40(100)$ & $98003.39(100)$ & 185681 & 189.46 \\
\hline \multicolumn{6}{|c|}{ Return structure } \\
\hline 18 & Yield (quintal/acre) & 456.25 & 210.78 & 245.47 & 116.46 \\
\hline 19 & Sale price (Rs. /quintal) & 938.73 & 655 & 283.73 & 43.32 \\
\hline 20 & Gross return & 428298.6 & 145478.9 & 282819.7 & 194.41 \\
\hline 21 & $\begin{array}{l}\text { Return over variable } \\
\text { cost }\end{array}$ & 265116.22 & 76270.25 & 188846 & 247.60 \\
\hline 22 & Net return & 144614.19 & 47475.51 & 97138.68 & 204.61 \\
\hline
\end{tabular}

Note- figures in parentheses indicate their percentages to total cost

be Rs. 69208.65. The cost structure of the total variable cost indicates that the highest proportion was spent on harvesting with Rs. 30505.26 (31.13\%) followed by plant protection, fertilizer and FYM, seed, weed control, field preparation, ridging/bed preparation and irrigation charges with Rs. 8000 (8.16\%), Rs. 7252.1 (7.40\%), Rs. 5394.73 (5.50\%), Rs. 4778.94 (4.88\%), Rs. 4289.47 (4.38\%), Rs. 1926.31 (1.97\%) and Rs. 1347.36 (1.37\%), respectively.

The finding of the study indicated in Table 1 shows that the total cost incurred on cucumber under polyhouse and open field condition was worked out Rs. 283684.40 and Rs. 98003.39 per acre respectively.
It is also shown in Table that the highest proportion in total cost of cucumber cultivation under polyhouse was incurred on variable cost $(57.52 \%)$. The share incurred on depreciation and interest on fixed capital (18.85\%) under polyhouse. The proportion spend on rental value of land in cost of cultivation of cucumber under polyhouse and open fields was worked out to be 6.25 per cent and 10.20 per cent respectively. In cost of cultivation of cucumber under polyhouse and open filed the proportion of management and risk factor each was worked out 5.75 and 7.06 per cent respectively. The analysis of data explains that the share of variable cost to total cost was worked out 
57.52 and 70.62 per cent under polyhouse and open field condition respectively.

An average yield of 456.25 and 210.78 quintal per acre was obtained under polyhouse and open field cultivation of cucumber respectively. Thus in open field cultivation of cucumber the yield was estimated 245.47 quintal/ acre less than the production under polyhouse cultivation. Similar findings are also reported by Kumar et al. (2016) who concluded that the farmers realized 53.71 $\%$ higher yield of tomato under poly house as compared to open field conditions while sale price received by polyhouse and open filed growers was Rs. 938.73 and Rs. 655 per quintal, respectively.

Present study represents also that, in case of polyhouse cultivation of cucumber, gross return per acre was estimated Rs. 428298.6 while in case of open field condition it was estimated Rs. 145478.9. Return over variable cost and net returns in polyhouse were calculated Rs. 265116.22 and Rs. 144614.19 per acre and it was Rs. 76270.25 and Rs. 47475.51 per acre in case of open field condition. Similar results were also in study of Kumar et al. (2016) who found that yield of capsicum and income of farmers can be taken more from polyhouse technology as compared to open field condition in Haryana,

Total cost under polyhouse and open field condition was worked out to be Rs. 283684.40 and Rs. 98003.39 per acre, respectively. The reasons for higher total cost were high price of seed/seedlings, large number of labour required and depreciation and interest on fixed cost which increases the total cost of cucumber cultivation under polyhouse.

The data related to percentage difference between cucumber cultivation under polyhouse and open field condition are also shown in table 1 . The table reveals that in case of variable cost, maximum difference was observed for seed Rs. 65477.17 which was more than twelve times as compared to open field condition. Similar findings reported by Nagalakshmi et al. (2001) who concluded that the capsicum crops grown in the naturally ventilated poly house had 4 times more yield and yield components compared to those grown in the field of Karnataka. This was followed by ridging/bed preparation, fertilizer and manures, field preparation, plant protection and harvesting with Rs. 5768.13 (299.44\%), Rs. 4726.3 (65.17\%), Rs. 2060.53 (48.04\%), 3256.94 (40.71\%) and Rs. 5973.9 (19.58\%), respectively. The plausible reasons for such heavy differences were, in polyhouse more seedlings were planted and these were costlier also. Field preparation and bed preparation cost was also found higher in polyhouse because more agronomical practices were performed during cultivation. The proportion spent on harvesting (Rs. 36479.16) was 19.58 per cent higher as compared to the open field condition (Rs. 30505.26). This was because of more number of skilled labour being used and also due to long harvesting period of cucumber in polyhouse as compared to open field condition. The results further reveal that the expenditure on irrigation and weed control was higher in case of open field condition by Rs. 654.4 (41.80\%) and Rs. $383.02(7.40 \%)$, respectively as compared to cultivation under polyhouse. This indicates that there was more infestation of weed in case of cultivation of cucumber under open field condition. Again marketing cost under polyhouse was higher by Rs. 6286.46 (141.26\%) as compared to open field condition.

Farmers realized that yield of cucumber under polyhouse is higher (145.32 per cent) as compared to open field condition. The gross return, returns over variable cost and net return were also higher by 272.01 per cent, 336.62 per cent and 208.43 per cent, respectively in case of polyhouse as compared to open field condition. Hence, it can safely be concluded that yield of cucumber and income of farmers can be increased by adoption of polyhouse technology.

\section{Conclusion}

The present study concluded that in economic analysis of cucumber, in case of variable cost, maximum difference was observed for seed which was more than twelve times as compared to open field condition. The use of fertilizers was more by 65.17 percent in case of polyhouse. In case of open field condition, expenditure on irrigation and weed control was higher by 9.91 and 19.15 per cent respectively. Total cost of cucumber in polyhouse was nearly two times higher as compared to open field condition. Farmers realized 145.32 per cent higher yield of cucumber under polyhouse as compared to open field condition. The gross returns and net returns in case of cucumber in polyhouse were found more as compared to open field cultivation. The gross return, returns over variable cost and net return were also higher by 272.01 per cent, 336.62 per cent and 208.43 per cent, respectively in case of polyhouse as compared to open field condition. Present study also concluded that technical support was major constraint also. So, government should address the problem of better technical support for wider adoption this crop.

\section{REFERENCES}

Anonymous (2012). Model Bankable Project on Protected Cultivation in Haryana. NABARD and Department of Horticulture, Government of Haryana.

Anonymous (2015). Horticultural Statistics at a Glance. Horticulture Statistics Division, Department of Agriculture, Cooperation \& Farmers Welfare Ministry of Agriculture \& Farmers Welfare, Government of India.

Sreedhara, D.S., Kerutagi, M.G., Basavaraja, H., Kunnal, L.B., Dodamani, M.T. (2013). Economics of capsicum production under protected condition in Northern Karnataka. Karnataka Journal Agriculture Science. 26 (2): 217-219

Kumar, P., Chauhan, R.S., Grover, R.K. (2016). Economic analysis of capsicum cultivation under polyhouse and 
Parveen Kumar et al. / J. Appl. \& Nat. Sci. 9 (1): 402 - 405 (2017)

open field condition in Haryana. International Journal of Farm Sciences, 6(1): 96-100

Kumar, P., Chauhan, R.S., Grover, R.K. (2016). Economics analysis of tomato cultivation under poly house and open field conditions in Haryana, India. Journal of
Applied and Natural Science. 8 (2): 846 - 848

Nagalakshmi, S., Nandakumar, N., Palanisamy, D., Sreenarayanan V.V. (2001). Naturally ventilated polyhouse for vegetable cultivation. South Indian Horticulture. 49: 345-346 